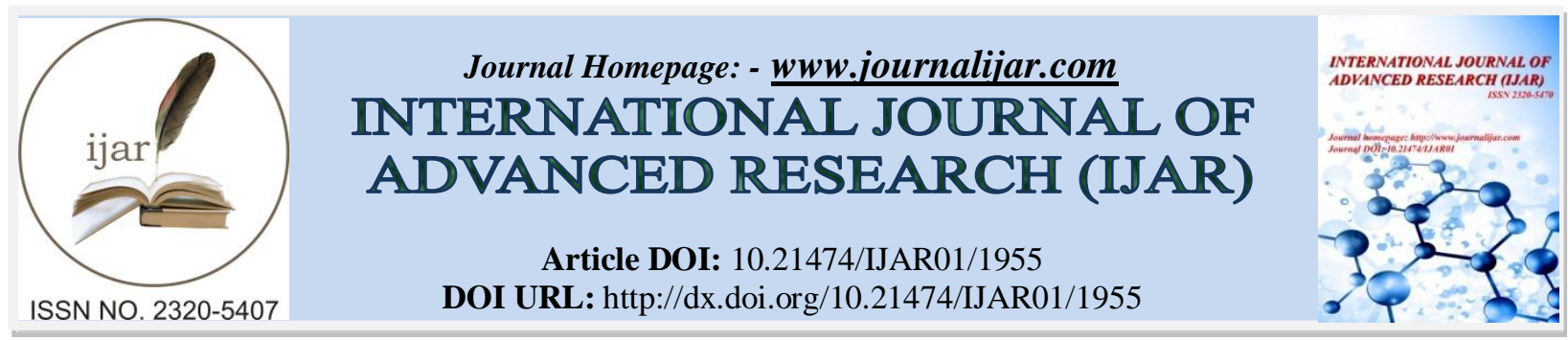

RESEARCH ARTICLE

\title{
EVALUATION OF URINARY CD4 T-CELL LEVELS AS A BIO-MARKER FOR LUPUS NEPHRITIS AND ITS CORRELATION WITH DISEASE ACTIVITY.
}

Mohammad A. Zakaria ${ }^{1}$, Doaa M. Sharaf ${ }^{2}$, Ibrahim T. Abdelal ${ }^{2}$ and Ghada M. Elakad ${ }^{3}$.

1. Rheumatology, Physical Medicine \& Rehabilitation Department, Faculty of Medicine, Ain Shams University, Egypt.

2. Rheumatology, Physical Medicine \& Rehabilitation Department, Faculty of Medicine, Zagazig University, Egypt.

3. Clinical Pathology Department, Faculty of Medicine, Zagazig University, Egypt.

\section{Manuscript Info}

Manuscript History

Received: 22 August 2016

Final Accepted: 25 September 2016

Published: October 2016

Key words:-

Lupus nephritis, Systemic Lupus

Erythematosus, SLE, Urinary CD4 T-

cells, Flow cytometry.

\section{Abstract}

Background:- Although renal biopsy is the most accurate method for assessing renal inflammation in patients with lupus nephritis (LN), the technique is invasive and cannot be performed frequently. There is a critical need to identify biomarkers for systemic lupus erythematosus (SLE) which has a high prevalence of renal failure.

Objective:- Our objective was to evaluate the level of urinary CD4 Tcells as a biomarker of active $\mathrm{LN}$ and indicator of treatment response in patients with SLE compared with normal control and its correlation with disease activity.

Subjects and methods:- 64 patients with SLE and 20 age \& sex matched control group were included. Patients were classified into two groups A \& B. Group A with LN and moderate to severe SLE disease activity, Group B without LN and mild to inactive SLE. Levels of urinary CD4 T-cell were quantified using flow cytometry in both patients' groups and controls at baseline and repeated for patients' groups only after 6 months.

Results:- We found that CD4 T-cell level in Group (A) was significantly higher at baseline than in Group (B). There was significant decrease in the CD4 $\mathrm{T}$-cell number in group $\mathrm{A}$, when repeated after 6 months. Number of CD4 T- cells was correlated significantly with the disease activity both at baseline and after 6 months. In healthy controls, the urine was almost devoid of CD4Tcells.

Conclusion:- Urinary CD4 T-cells is a good non-invasive marker for detecting active LN in SLE patients and also is a good monitor for treatment efficacy.

Copy Right, IJAR, 2016,. All rights reserved.

\section{Introduction:-}

Systemic lupus erythematosus (SLE) is a typical autoimmune disease characterized by the production of a wide array of autoantibodies which potentially drive immune-complex related inflammation into various tissues and organs. Thus, the condition was traditionally classified as a "B-cell disease"[1]. Compelling evidence has however 
shown that without the assistance of the helper T lymphocytes, it is indeed difficult for the "helpless" B cells to become functional enough to trigger SLE-related inflammation [2]. T-cells have been recognized to be crucial in the pathogenicity of SLE through their capabilities to communicate with and offer enormous help to B cells for driving autoantibody production through stimulating the latter to differentiate, proliferate and mature. Abnormalities in adaptive immunity triggered by genetic and environmental factors are thought to play an important role in the pathogenesis of SLE[3]. Renal involvement becomes clinically apparent in approximately 75\% of SLE patients; however, most of the remaining patients have subclinical disease that can be demonstrated if renal biopsy were performed. Renal affection usually develops in the first few years of illness and should be detected early by periodic urine analysis and estimation of the glomerular filtration rate [4]. Despite advances in the treatment of LN, the occurrence of nephritis is still associated with a significant burden of morbidity and mortality [5].The patient is threatened from two sides: under-treatment, implicating uncontrolled autoimmunity and overtreatment, resulting in toxicity and danger of serious infections [6]. A diagnosis of LN is usually suspected in patients with systemic signs of SLE activity and urinary abnormalities and is confirmed by kidney biopsy.The sooner the diagnosis of LN is established, the better the prognosis [7]. However,urinary findings may be misleading or unspecific, while kidney biopsy is an invasive procedure not free from risk [8].An ideal biomarker would non- invasively identify patients with acute LN and quantitatively reflect the inflammation in the kidneys to allow monitoring of the disease and patient tailored treatment. Enghardand his colleagues hypothesized that an SLE marker specific for LN would most likely to be found in urine. They reported that CD4 T-cells can be found in abundance in the urine of the patient with active LN [9].Infiltration of inflammatory cells into the kidneys is a well-established element of LN, particularly the proliferative forms [10]. This infiltration predominantly consists of CD4 T-cells and the extent of the infiltration is one of the best predictors of renal outcome [11]. The phenotype of the CD4 T-cells in the urine is qualitatively reminiscent of the renal infiltrating cells rather than the T-cells circulating in the peripheral blood [12]. Hence, it is reasonable to assume that the $\mathrm{CD} 4 \mathrm{~T}$ - cells found in the urine originate from the inflamed kidney interstitium and this is strengthened by the observed close correlation with LN activity.

\section{Objective:-}

Our objective was to evaluate the level of urinary CD4 T-cells as a biomarker of active LN and indicator of treatment response in patients with SLE compared with normal healthy control and its correlation with disease activity.

\section{Subjects and methods:-}

Sixty-four patients with SLE were selected from the Outpatients Clinics and Inpatients Units of Rheumatology and Rehabilitation Department, Zagazig University Hospitals, were included in this study, their age ranged between 2048 years. All SLE patients satisfied the Systemic Lupus International Collaborating Clinics (SLICC) group revised SLE Classification Criteria[13].Twenty age and sex matched healthy volunteers were selected as a control group. For all patients, the Systemic Lupus Erythematosus Disease Activity Index (SLEDAI) was calculated [14]. Patients with a SLEDAI $\geq 10$ were considered to have moderate to severely active SLE disease, patients with a SLEDAI $<10$ were considered to have inactive to mild active disease. The diagnosis of active lupus nephritis was made based on the fulfillment of any two of the following 3 criteria: (1) a level of glomerular erythrocytes of $>50 \%$ and/or hematuria and/or the presence of hyaline or cellular casts.(2) A quantitative 24-hour urinary protein level of $>1 \mathrm{gm}$ or increase in the level of $>0.5 \mathrm{gm}$ over a two to three-month period. (3) Evidence of one or more active lesions on a renal biopsy based on the Classification Criteria for $\mathrm{LN}$ established by the International Society of Nephrology/Renal Pathology Society [15].Complete remission was defined as the absence of activity in the urinary sediment and a quantitative 24 -hour urinary protein level of $<0.5 \mathrm{gm}$ within the previous three months [16].

\section{Exclusion criteria:-}

Patients with other nephropathy as diabetic nephropathy, ANCA- associated vasculitis were excluded. Patients with urinary tract infection, renal cancer or renal failure and patients with other autoimmune disease were also excluded.

The study was approved by the ethics committee of the Zagazig University hospitals, Faculty of Medicine, Zagazig University and the patients were included in the study after giving their informed consent after explanation of the purpose and procedures of the study.

Patients were classified into two groups:-

Group (A):- Included 40 patients with LN and a SLEDAI $\geq 10$ (4 males, and 36 females with a mean age of $34.6 \pm 6.4$ years). 
Group (B):- Included 24 patients with no LN and the SLEDAI < 10 (4 males, and 20 females with a mean age of 32.1 \pm 5.7 years).

\section{All patients were subjected to:-}

1. Complete history taking including the duration of the disease, history of renal involvement (LN) or renal biopsy and drug therapy.

2. General and complete musculoskeletal examinations including assessment of disease activity by SLEDAI.

3. Complete neurological examination.

4. Routine laboratory investigations were done, as complete blood count (CBC) on SysmixKx 21 automatic cell counter (Japan). Liver, kidney function tests, 24h urine protein, CRP on CobasInegra 400 (Roche Diagnostic, Germany). Determination of complement C3 and C4 levels in serum was done on automated BN Prospec (Siemens Diagnostic, Germany). Antinuclear antibody (ANA) and Anti- double stranded DNA (anti-dsDNA) were measured by indirect immunofluorescence assay (IIF) on mouse kidney and stomach slides (ImmunoDiagnostic, USA).

5. Urinary CD4 T-cell: Urine samples were collected from 64 patients with SLE and 20 healthy controls were monitored for the presence of CD4T-cells at baseline and repeated measurements after 6 months were done for the patients only. The median sample size was $100 \mathrm{ml}$ urine; the usual standing time for the urine was 4-6 hours.

\section{Flow cytometry method:-}

In this prescriptive study 4 colors was used to quantify the percent and events of CD4 in the monoclonal cells of urine sample, so for assessment we used CD4 PE , CD3 Prep, CD45 FITC and the urine sample were collected immediately, centrifuged and washed 3 times with phosphate buffer solution (PBS), then we incubate the pellet with monoclonal Abs for assessment with flow cytometry, also we added PromodiumIodid (Eugene ,Oregon , USA) immediately before assay on flow cytometryto exclude dead cells.For each sample up to 10.000 cells were acquired and according to the plot of Side Scatter Scale versus CD45 stain our data was visualized. Lymphocyte populations were identified based on low Side Scatter and a combination of low intensity CD45 expression with CD4 CD3. The data were collected using (FACS Caliber,Becta-Dickinson BD and San Diago, USA).

\section{Statistical analysis:-}

IBM SPSS statistics (V. 22.0, IBM Corp., USA, 2013) was used for data analysis. Date were expressed as Mean \pm SD for quantitative parametric measures in addition to both number and percentage for categorized data.

The following tests were done:

1. Comparison between two independent mean groups for parametric data using Student $t$ test.

2. Comparison between 2 dependent groups for parametric data using Paired $t$ test.

3. Pearson correlation test to study the possible association between each two variables among each group for parametric data.

The probability of error at 0.05 was considered significant, while at 0.01 and 0.001 was considered highly significant.

\section{Results:-}

General and clinical characteristics of patients groups and the healthy controls were shown in Table (1). We found that in group (A) 22 patients (55\%) out of 40 with past history of renal biopsy revealed grade 2 and 3 proliferative nephritis. Laboratory results of patient groups at baseline shown in Table (2). The mean of CD4 T-cells in group (A) was high $=2400.9 \pm 879.3 \mathrm{CD} 4 \mathrm{~T}$-cells $/ 100 \mathrm{ml}$ urine at baseline, Table (3). In patients with LN group (A) the number of urinary CD4 T-cells in $100 \mathrm{ml}$ urine clearly correlated significantly with the disease activity both at baseline and after 6 months (Table 5 and figures $1 \& 2$ ). And when repeated after 6 months the mean of CD4 T-cell number decreased significantly in group A indicating good response to treatment (Table 4). While, in group (B), SLE patients without LN and with mild or no active disease, a mean of 165 $\pm 22.4 \mathrm{CD} 4 \mathrm{~T}$-cells/100 ml was found with no significant changes in numberof CD4 T-cells were detected after 6 months and its number did not correlate with mean SLEDAI or therapy (Tables 4\& 5). In healthy controls, the urine was almost devoid of CD4 T-cells and a mean of $2.3 \pm 0.3 \mathrm{CD} 4 \mathrm{~T}$-cells $/ 100 \mathrm{ml}$ urine were found, which was significantly fewer than that observed in patients with SLE, regardless of disease activity or renal involvement Table (3). 
Table 1:- General and clinical characteristics of both patients and controls (Mean \pm SD).

\begin{tabular}{|c|c|c|c|c|c|}
\hline \multicolumn{2}{|c|}{ The characteristic } & $\begin{array}{c}\text { Group }(A) \\
\text { LN with SLEDAI } \geq \mathbf{1 0}\end{array}$ & $\begin{array}{c}\text { Group (B) } \\
\text { No LN with SLDAI }<10\end{array}$ & Healthy controls & P-Value \\
\hline \multicolumn{2}{|c|}{ Number } & 40 & 24 & 20 & --- \\
\hline \multicolumn{2}{|c|}{ Age (year) } & $\begin{array}{c}22-45 \\
34.6 \pm 6.4\end{array}$ & $\begin{array}{c}20-42 \\
32.1 \pm 5.7\end{array}$ & $\begin{array}{c}20-40 \\
31.7 \pm 6.9\end{array}$ & $>0.05$ \\
\hline \multicolumn{2}{|c|}{$\mathbf{F} / \mathbf{M}$} & $36 / 4$ & $20 / 4$ & $18 / 2$ & $>0.05$ \\
\hline \multicolumn{2}{|c|}{$\begin{array}{c}\text { Duration of disease } \\
\text { (years) }\end{array}$} & $\begin{array}{c}2-13 \\
6.1 \pm 2.4\end{array}$ & $\begin{array}{c}1.5-10 \\
5.7 \pm 1.2\end{array}$ & - & $>0.05$ \\
\hline \multicolumn{2}{|c|}{ SLEDAI } & $\begin{array}{c}(10-24) \\
15.1 \pm 3.7\end{array}$ & $\begin{array}{c}(2-9) \\
6.2 \pm 2.2\end{array}$ & - & $<0.001$ \\
\hline \multirow{5}{*}{ 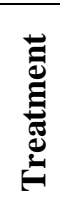 } & Steroid & $40(100 \%)$ & $24(100 \%)$ & - & --- \\
\hline & CYX & $26(65 \%)$ & - & - & --- \\
\hline & AZA & $6(15 \%)$ & $20(83.3 \%)$ & - & --- \\
\hline & MMF & $8(20 \%)$ & - & - & --- \\
\hline & HCQ & $38(95 \%)$ & $22(91.6 \%)$ & - & --- \\
\hline \multicolumn{2}{|c|}{ Renal biopsy } & $22(55 \%)$ & - & - & --- \\
\hline
\end{tabular}

SLEDAI=SLE disease activity index, $\mathrm{CYX}=$ Cyclophosphamide, AZA=Azathioprine

$\mathrm{MMF}=$ Mychophenolatemofetil, $\mathrm{HCQ}=$ Hydroxychloroquine.

Table 2:- Laboratory results of both groups at the baseline (Mean $\pm \mathrm{SD})$ :

\begin{tabular}{|c|c|c|c|}
\hline Lab. Test & $\begin{array}{c}\text { Group (A) } \\
(\text { No.=40) }\end{array}$ & $\begin{array}{c}\text { Group (B) } \\
(\text { No.=24) }\end{array}$ & P-Value \\
\hline ESR mm/h & $\begin{array}{c}46-76 \\
61.7 \pm 11.2 \\
\end{array}$ & $\begin{array}{c}23-37 \\
30.1 \pm 6.9\end{array}$ & $<0.001$ \\
\hline CRP & $\begin{array}{c}6-10 \\
8.1 \pm 2.3 \\
\end{array}$ & $\begin{array}{c}1-6 \\
3.7 \pm 1.1 \\
\end{array}$ & $<0.001$ \\
\hline S.Urea mg/L & $\begin{array}{c}25-55 \\
34.9 \pm 10.3 \\
\end{array}$ & $\begin{array}{c}12-25 \\
18.4 \pm 6.4 \\
\end{array}$ & $<0.001$ \\
\hline S.Creat mg/dl & $\begin{array}{l}0.9-2.8 \\
1.9 \pm 0.7 \\
\end{array}$ & $\begin{array}{c}0.5-1.1 \\
0.8 \pm 0.3 \\
\end{array}$ & $<0.001$ \\
\hline +ve ANA & $36(90 \%)$ & $22(91.6 \%)$ & $>0.05$ \\
\hline +ve Anti ds-DNA & $28(70 \%)$ & $10(41.6 \%)$ & $<0.05$ \\
\hline C3 mg/dl & $\begin{array}{c}52-72.5 \\
64.5 \pm 10.9\end{array}$ & $\begin{array}{c}75-135 \\
99.3 \pm 20.4\end{array}$ & $<0.001$ \\
\hline C4 mg/dl & $\begin{array}{c}9-13.2 \\
10.1 \pm 3.9\end{array}$ & $\begin{array}{c}18.5-40 \\
29.4 \pm 11.7 \\
\end{array}$ & $<0.001$ \\
\hline Protein in $\mathrm{mg}$ / $24 \mathrm{~h}$ urine & $\begin{array}{c}1300-5600 \\
3070.3 \pm 500.4\end{array}$ & $\begin{array}{c}150-350 \\
290.4 \pm 80.9\end{array}$ & $<0.001$ \\
\hline
\end{tabular}

Table 3:- Range and mean levels of urinary CD4 T-cells at baseline in patients and controls:

\begin{tabular}{|l|c|c|c|}
\hline & Range (cells/100 ml) & Mean \pm SD & P-Value \\
\hline Group (A) & $1300-4200$ & $2400.9 \pm 879.3$ & $<0.001$ \\
\hline Group (B) & $150-240$ & $165 \pm 22.4$ & \\
\hline Control group & $0-5$ & $2.3 \pm 0.3$ & \\
\hline
\end{tabular}

Table 4:- Comparison between levels of urinary CD4 T-cells and SLEDAI in patients' groups at baseline and after 6 months:

\begin{tabular}{|l|c|c|c|c|c|c|}
\hline & \multicolumn{2}{|c|}{ CD4 T-cells/100 ml (Mean \pm SD) } & \multirow{2}{*}{ P-Value } & \multicolumn{2}{|c|}{ SLEDAI (Mean \pm SD) } & P-Value \\
\cline { 2 - 3 } \cline { 5 - 7 } & At baseline & After 6 months & & At baseline & $\begin{array}{l}\text { After 6 } \\
\text { months }\end{array}$ & \\
\hline Group (A) & $2400.9 \pm 879.3$ & $2054.8 \pm 411.4$ & $<\mathbf{0 . 0 5}$ & $16.5 \pm 5.9$ & $7.4 \pm 1.7$ & $<\mathbf{0 . 0 0 1}$ \\
\hline Group (B) & $165 \pm 22.4$ & $154 \pm 18.4$ & $\mathbf{> 0 . 0 5}$ & $6.2 \pm 2.2$ & $5.8 \pm 2.8$ & $>\mathbf{0 . 0 5}$ \\
\hline
\end{tabular}


Table 5:- Correlation between levels of urinary CD4 T- cells and SLEDAI in patients' groups at baseline.

\begin{tabular}{|c|c|c|c|c|c|}
\hline \multicolumn{2}{|c|}{} & CD4 T-cells/100 ml & SLEDAI & r & P-Value \\
\hline \multirow{2}{*}{ Group (A) } & At baseline & $2400.9 \pm 879.3$ & $16.5 \pm 5.9$ & 0.522 & $<0.001$ \\
\cline { 2 - 6 } & $\begin{array}{c}\text { After 6 } \\
\text { months }\end{array}$ & $2054.8 \pm 411.4$ & $7.4 \pm 1.7$ & 0.436 & $<0.001$ \\
\hline
\end{tabular}

Figure 1:- Correlation study between CD4 T-cells and SLEDAI among group-A patients at baseline:

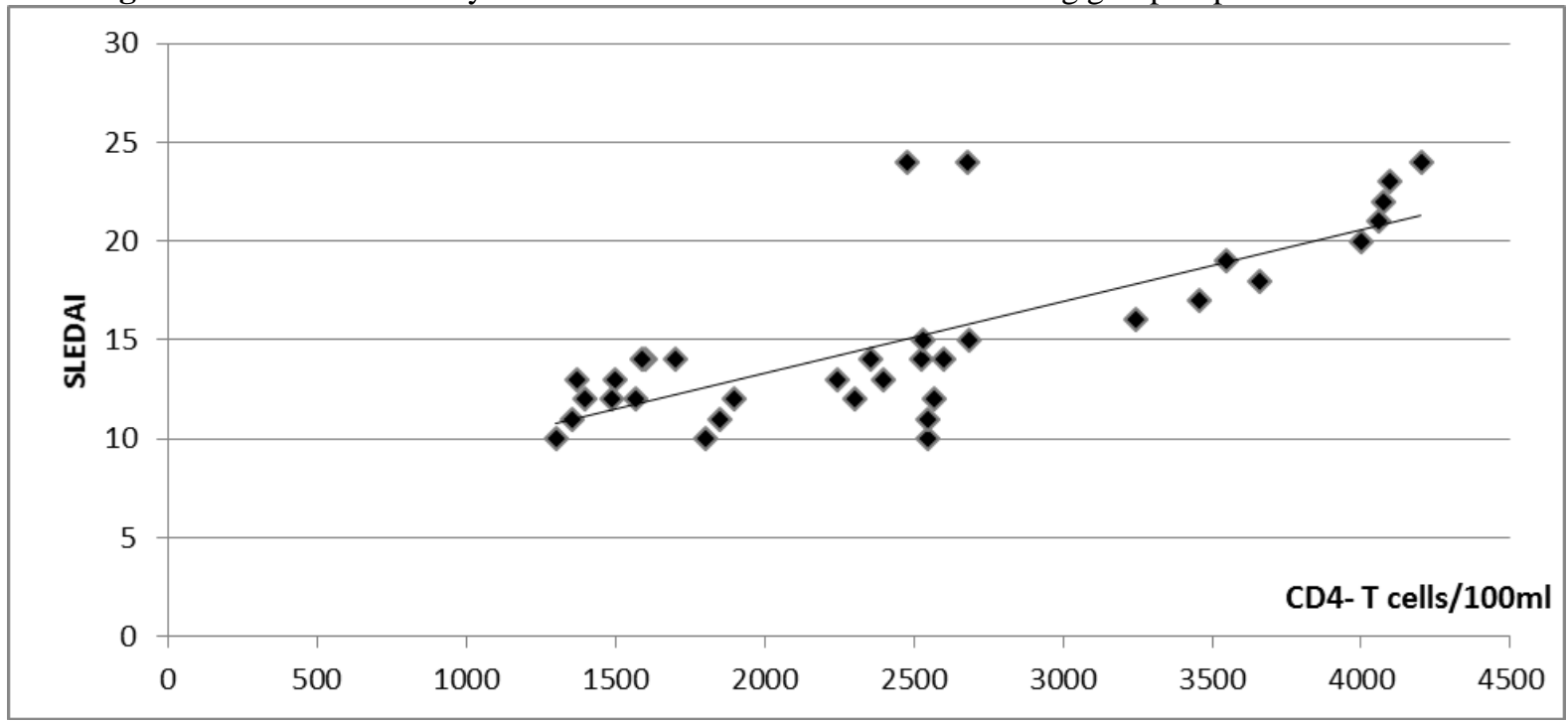

Figure 2:- Correlation study between CD4 T-cells and SLEDAI among group-A patients after 6 months.

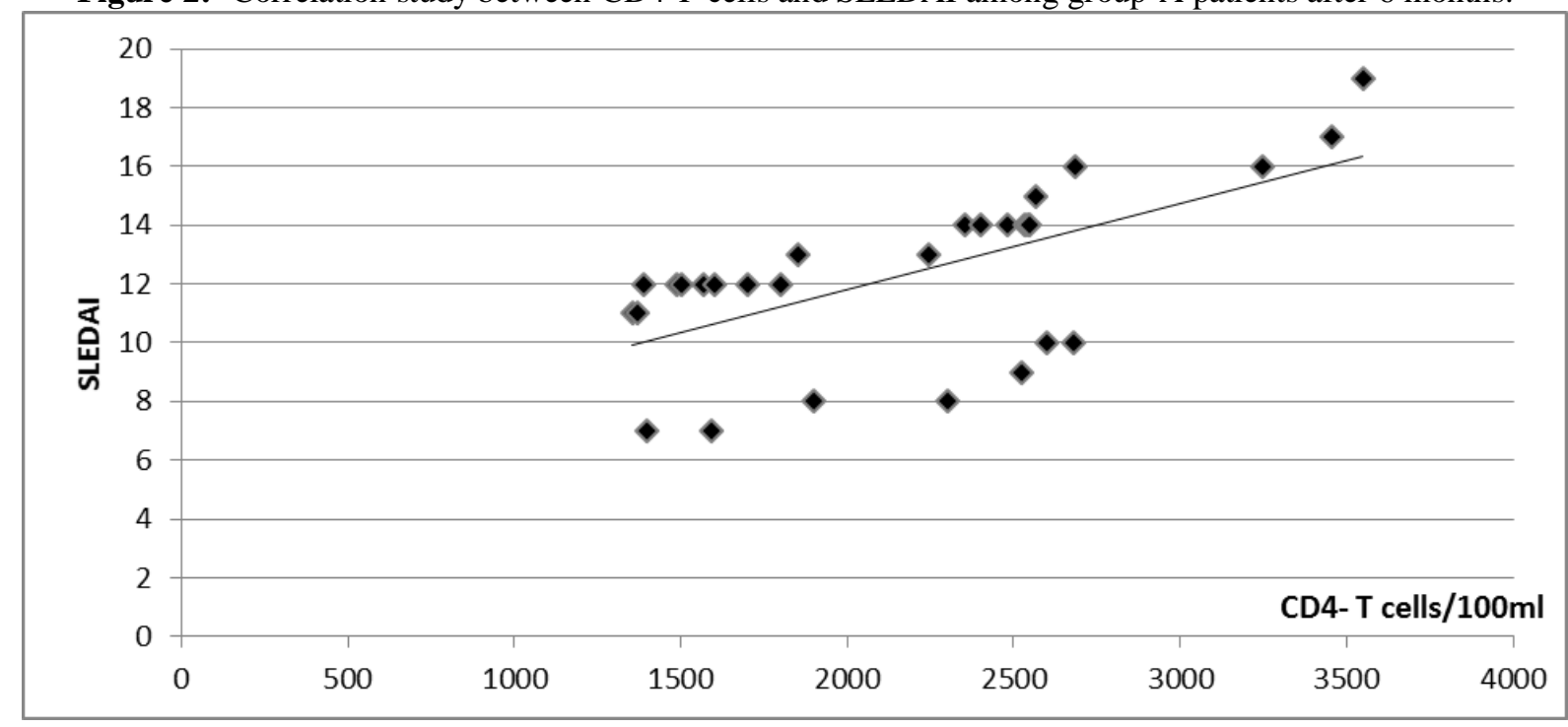

\section{Discussion:-}

Currently, patients with SLE are mainly screened for renal involvement using creatinine levels, proteinuria and urinary sediment[17]. Although useful, these variables have certain limitations. Creatinine levels and proteinuria can be persistently elevated and therefore unable to differentiate present kidney damage from acute nephritis. The mainstay for diagnosing LN is the renal biopsy, which is not free from risk and is not suitable for monitoring followup[9]. Several urinary biomarkers have been proposed in recent years, most of them detected by ELISA or reverse transcription PCR [18 \& 19].Massengill and his colleagues were the first to report oligoclonal expansions of T cells in lupus nephritis [20] and this was confirmed by Murata and his colleagues[21]. However, they found no evidence 
of clonal sharing with the blood, and didn't determine whether these expansions were members of the CD4 or CD8 T-cell subset or how they related to lupus nephritis.

To better define the immunologic character of the $\mathrm{T}$ cell infiltrate in lupus nephritis, Winchester and his colleagues reported that SLE kidneys have a variably patterned and often extensive infiltrate of predominantly expanded T cells of CD4 and CD8 lineages. CD4 T-cells were prominent in nearly two thirds of SLE biopsies and distributed as broad aggregates or intermixed with CD8 T-cells forming periglomerular caps. The immunological characteristics of the infiltrating CD4 and CD8 T-cells in the lupus kidney indicate they have the potential to mediate injury, which may be relevant to development of progressive renal failure. The high frequency of CD4 T-cells in the interstitial infiltrates of patients with LN suggests a contribution of these cells to the local pathogenesis[22].

In a study done by Moonand his colleagues, they indicated that intra-renal infiltration and activation of T-cells in the interstitium is the main mechanism of kidney injury and showed a predominant CD4 T-cell renal infiltration [23]. Another study reported that in LN the interstitial infiltration consists mainly ofT-cells and to lesser extent of macrophages, B-cells and plasma cells [24]. Enghard and his colleaguesdetermined whether the infiltrating T cells could be monitored in the urine to provide a reliable biomarker for acute LN. The frequency of CD4 T-cells was determined by flow cytometry of peripheral blood and urine from 38 patients with SLE and the values were compared with disease activity as determined by the SLEDAI.The number of urinary CD4 T-cells reflected nephritis activity and elevation above $800 \mathrm{CD} 4 \mathrm{~T}$-cells per $100 \mathrm{ml}$ of urine sharply delineated active from inactive nephritis. Moreover, the frequency of urinary CD4 T-cells correlated with the disease activity [12].

In our study, we found that urinary CD4 T-cell counts were increased significantly in active SLE patients with severe nephritis and the SLEDAI $\geq 10$, with a mean urinary CD4 T-cell count of (2400.9 \pm 879.3 cells/100 mlurine) in patients of group (A). While in group (B) the mean of CD4 T-cells was low (165 222.4 cells $/ 100 \mathrm{ml}$ urine) and there was significant correlation between the level of CD4 T-cells and SLEDAI score. These results were in agreement with Enghardand his colleagues[9] who measured the level of urinary CD3CD4 T-cells using flow-cytometry in 186 urine samples from 147 patients with SLE. Fourteen patients were monitored as follow-up. Thirty-one patients with other nephropathies and 20 healthy volunteers were included as controls. In SLE, urinary CD4 T- cell counts $\geq 800 / 100 \mathrm{ml}$ were observed exclusively in patients with active LN. In patients monitored under therapy, normalization of urinary CD4 T-cell counts indicated lower disease activity and better renal function. In contrast, patients with persistence of, or increase in, urinary T-cells displayed worse outcomes. Our results agreed also withKopetschkeand his colleagues[25], who studied 98 patients with SLE,19 with active renal involvement defined by (SLEDAI $\geq 10 \&$ a current renal biopsy showed LN or at least two elements of the renalSLEDAI in the absence of a biopsy) and 79 patients with non-active renal involvement. Urine samples from patients with active renal involvement had higher numbers of CD4 (median of 1415 cells/100 ml urine), in SLE patients without active renal involvement only low number of T-cells was detected with a median of 29 CD4 T-cells/100ml urine).

\section{Conclusion:-}

Urinary CD4 T-cells marker has a valuable role in detecting LN in SLE patients and has significant correlation with disease activity index. Furthermore, monitoring urinary CD4 T-cells may help to identify treatment responders and treatment failure and enable patient-tailored therapy in the future.

\section{Conflict of interest:-}

The authors declare they have no conflicts of interest.

\section{References:-}

1. Tsokos GC. Systemic lupus erythematosus. N Engl J Med. 2011; 365(22): 2110-21.

2. Mak A, Kow NY. The Pathology of T Cells in Systemic Lupus Erythematosus. J Immunol Res. 2014; 2014 : 419029.

3. Zhang S, Lu X, Shu X, TianX, Yang H, YangW, et al. Elevated Plasma cfDNA May be Associated with Active Lupus Nephritis and Partially Attributed to Abnormal Regulation of Neutrophil Extracellular Traps (NETs) in Patients with Systemic Lupus Erythematosus. Intern Med. 2014; 53(24): 2763-71.

4. Buyon J. Systemic Lupus Erythematosus A- Clinical and Laboratory Features. In: John H. Klippel, Primer on the Rheumatic Diseases 2008; Page: 303-18. 
5. Ward MM. Changes in the incidence of end-stage renal disease due to lupus nephritis in the United States, 1996-2004. J Rheumatol. 2009; 36(1): 63-7.

6. Moore RA, Derry S. Systematic review and meta-analysis of randomised trials and cohort studies of mycophenolate mofetil in lupus nephritis. Arthritis Res Ther. 2006; 8(6): R182.

7. Faurschou M, Starklint H, Halberg P, Jacobsen S.Prognostic factors in lupus nephritis: diagnostic and therapeutic delay increases the risk of terminal renal failure. J Rheumatol. 2006; 33(8): 1563-9.

8. Preda A, Van Dijk LC, Van Oostaijen JA, Pattynama PM.Complication rate and diagnostic yield of 515 consecutive ultrasound-guided biopsies of renal allografts and native kidneys using a 14-gauge Biopty gun. EurRadiol. 2003; 13(3): 527-30.

9. Enghard P, Rieder C, Kopetschke K, Klocke JR, Undeutsch R, Biesen R, et al. Urinary CD4 T cells identify SLE patients with proliferative lupus nephritis and can be used to monitor treatment response. Ann Rheum Dis. 2014; 73(1): 277-83.

10. Yu F, Wu LH, Tan Y, Li LH, Wang CL, Wang WK, et al. Tubulointerstitial lesions of patients with lupus nephritis classified by the 2003 International Society of Nephrology and Renal Pathology Society system.Kidney Int. 2010; 77(9): 820-9.

11. Caligaris-Cappio F, Bergui L, Tesio L, Ziano R, Camussi G. HLA-Dr+ T cells of the Leu 3 (helper) type infiltrate the kidneys of patients with systemic lupus erythematosus. ClinExpImmunol. 1985; 59(1): 185-9.

12. Enghard P, Humrich JY, Rudolph B, Rosenberger S, Biesen R, Kuhn A, et al. CXCR3+CD4+ T cells are enriched in inflamed kidneys and urine and provide a new biomarker for acute nephritis flares in systemic lupus erythematosus patients. Arthritis Rheum. 2009; 60(1): 199-206.

13. Petri M, Orbai AM, Alarcón GS, Gordon C, Merrill JT, Fortin PR, et al. Derivation and validation of the Systemic Lupus International Collaborating Clinics classification criteria for systemic lupus erythematosus. Arthritis Rheum. 2012; 64(8): 2677-86.

14. Hawker G, Gabriel S, Bombardier C, Goldsmith C, Caron D, Gladman D. A reliability study of SLEDAI: a disease activity index for systemic lupus erythematosus. J Rheumatol. 1993; 20(4): 657-60.

15. Weening JJ, D'Agati VD, Schwartz MM, Seshan SV, Alpers CE, Appel GB, et al. The classification of glomerulonephritis in systemic lupus erythematosus revisited. J Am SocNephrol. 2004; 15(2): 241-50.

16. Rosa RF, Takei K, Araújo NC, Loduca SM, Szajubok JC, Chahade WH.Monocyte chemoattractant-1 as a urinary biomarker for the diagnosis of activity of lupus nephritis in Brazilian patients. J Rheumatol. 2012; 39(10): 1948-54.

17. Hahn BH, McMahon MA, Wilkinson A, Wallace WD, Daikh DI, Fitzgerald JD, et al. American College of Rheumatology guidelines for screening, treatment and management of lupus nephritis. Arthritis Care Res (Hoboken). 2012; 64(6): 797-808.

18. Mok CC. Biomarkers for lupus nephritis: a critical appraisal. J Biomed Biotechnol. 2010; 2010: 638413.

19. Reyes-Thomas J, Blanco I, Putterman C. Urinary biomarkers in lupus nephritis. Clin Rev Allergy Immunol. 2011; 40(3): 138-50.

20. Massengill SF, Goodenow MM, Sleasman JW. SLE nephritis is associated with an oligoclonal expansion of intrarenal T cells. Am J Kidney Dis. 1998; 31(3): 418-26.

21. Murata H, Matsumura R, Koyama A, Sugiyama T, Sueishi M, Shibuya K, et al. T cell receptor repertoire of $\mathrm{T}$ cells in the kidneys of patients with lupus nephritis. Arthritis Rheum. 2002; 46(8): 2141-7.

22. Winchester R, Wiesendanger M, Zhang HZ, Steshenko V, Peterson K, Geraldino-Pardilla L, et al. Immunologic Characteristics of Intrarenal T cells: Trafficking of Expanded CD8 T Cell $\beta$-Chain Clonotypes in Progressive Lupus Nephritis. Arthritis Rheum. 2012; 64(5): 1589-600.

23. Moon JY, Jeong KH, Lee TW, Ihm CG, Lim SJ, Lee SH. Aberrant recruitment and activation of T cells in diabetic nephropathy. Am J Nephrol. 2012; 35(2): 164-74.

24. Boucher A, Droz D, Adafer E, Noël LH. Characterization of mononuclear cell subsets in renal cellular interstitial infiltrates. Kidney Int. 1986; 29(5): 1043-9.

25. Kopetschke K, Klocke J, Grießbach AS, Humrich JY, Biesen R, Dragun D, et al. The cellular signature of urinary immune cells in lupus nephritis: New insights into potential biomarkers. Arthritis Res Ther. 2015; 17: 94. 